\title{
PROBLEMATYKA TRWAKEGO POKOJU W UJĘCIU HISTORYCZNYM
}

Rozważania nad powyższym zagadnieniem koncentrują się w wielu wypadkach na jego aspektach moralno-prawnych ${ }^{1}$, w związku z czym celowe wydaje się wskazanie na zasadnicze przynajmniej projekty, zmierzające do eliminacji (lub ograniczenia) środków służących prowadzeniu wojen, jak również na próby rozstrzygania rysujących się konfliktów drogą mediacji. Przyjęte założenie sprawi, iż należałoby zwrócić baczniejszą uwagę na dwie sfery: delegalizacji wojny, bądź też jedynie pewnych jej przejawów, oraz demilitaryzacji. W obliczu ogromnej różnorodności inicjatyw wypowiedź poniższa stanowić będzie, potraktowaną zgoła wyrywkowo, egzemplifikację ważniejszych momentów tego procesu, przy równoczesnym wypreparowaniu ich z ideologiczno-doktrynalnego tła, na co można sobie pozwolić wobec dość bogatej literatury przedmiotu. Do zobrazowania charakteru delegalizacji posłużą zarówno te projekty, które pozostały w obrębie teorii, jak i te, które zmaterializowano w konkretnych aktach dyplomatycznych. Domeną demilitaryzacji są natomiast plany realnego zmniejszenia bądź tylko zahamowania zbrojeń, a tym samym pośrednio możliwości wybuchu konfliktu. Tak do źródeł, jak i do obszernego stosunkowo piśmiennictwa odwoływałem się jedynie w istotniejszych kwestiach.

Generalnie rzecz biorąc przyjmuje się, iż pierwociny idei pokojowego współistnienia sięgają początków czasów nowożytnych, niemniej wielu autorów dopatruje się jej analogii już w starożytności. Przywodzi się podówczas zwykle na pamięć pokój Nikiasza, zawarty między Atenami a Spartą zimą roku $422-421$. Obie strony poprzysięgły, iż przez 50 lat nie będą podejmować żadnych działań wojennych ani przeciw sobie, ani też Sparta nie zaatakuje sprzymierzeńców Aten. Wszelkie spory oddane być miały pod arbitraż, wszystkim też zawarowano nieskrępowany dostęp do ogólnogreckich miejsc kultu religijnego. Przyjęte wyżej zobowiązania miano potwierdzać corocznie. Nowe elementy pojawiły się wkrótce potem, w ogłoszonej przez Ateny w 377 roku Kar-

${ }^{1}$ Zob. dla przykładu: F. H. Hin sle y, Power and the Pursuit of Peace. Theory and Practice in the History of the Relations between States, Cambridge 1967; A. Der y ng, Kościót a zagadnienie pokoju, Lublin 1934; A. P a k ow ic z, Droga do delegalizacji wojny, „Zeszyty Historyczno-Polityczne Stronnictwa Demokratycznego" 1979 z. 2. 
cie Drugiego Związku Morskiego. Stanowiła ona, iż każde greckie lub niegreckie państwo może stać się sojusznikiem Aten i ich sprzymierzeńców, jeżeli utrzyma swą niezależność od Persji. Potencjalnym aliantom gwarantowano nienastawanie na ich dotychczasową wolność, zachowanie istniejącego ustroju, niezmuszanie ich ani do przyjęcia ateńskiego garnizonu, ani namiestnika oraz niepobieranie danin przeciw Sparcie. Zasadniczym celem Związku miało być stworzenie sytuacji, w której „Sparta pozwoliłaby państwom greckim żyć w pokoju, korzystać z wolności i autonomii i bezpiecznie władać własnym terytorium"2.

Warto w tym miejscu nadmienić, że dla starożytnych wojna była raczej wyrazem tego, co współcześnie określamy mianem racji stanu, a nie środkiem egzekucji sprawiedliwości i prawa. Lapidarnie ujął to wybitny historyk Tukidydes, syn Olorosa, pisząc, iż „dla króla czy rzeczypospolitej nic nie jest niesprawiedliwe, co jest pożyteczne"3.

Głębszy przełom w tej materii następuje jednak dopiero po narodzinach chrześcijaństwa. Kościół nie podzielał poglądów skrajnych pacyfistów, uznających wojnę za sprzeczną z zasadami wiary, ale przypisując państwu doniosłe funkcje w dziedzinie organizowania i ochrony bytu doczesnego, dostrzegał w orężu skuteczny środek trwałego zachowania związanych z tymże państwem wartości. Powyższe kwestie stały się przedmiotem rozważań sporego grona myślicieli ${ }^{4}$. Rezultaty ich prac inspirowały niejednokrotnie poczynania władców.

Z dorobku teoretycznego św. Augustyna (354 - 430) czerpal cesarz Zachodu Gracjan (375 - 383), który w jednym ze swych dekretów uznawał za wojny sprawiedliwe, a w związku z tym dopuszczalne, jedynie te, które służyć miały bądź to pomszczeniu bezprawia, bądź zwrotowi zagrabionych ziem czy mienia $^{5}$. Twórczą kontynuację tego nurtu stanowiły poglądy św. Tomasza z Akwinu (1225 lub nico później - 1274). Podstawowym warunkiem usprawiedliwiającym uciekanie się przez jedną ze stron do wojny, było doznanie przez nią znacznej krzywdy w połączeniu z odmową drugiej ze stron dania stosownego zadośćuczynienia. Kolejny wymóg zasadzał się w twierdzeniu, iż działania zbrojne prowadzić mogła jedynie władza najwyższa. Wreszcie trzeci z kardynalnych postulatów obligował pokrzywdzonego do limitowania swych poczynań proporcjonalnie do rozmiarów uczynionego mu deliktu' ${ }^{6}$. W wiekach średnich szczególnie doniosła była druga $\mathrm{z}$ reguł, albowiem toczone naonczas „wojny prywatne” stały się niekłamanym utrapieniem dla wszystkich, zwłasz-

${ }^{2}$ N. G. Ham mond, Dzieje Grecji, Warszawa 1973, s. 446-447, $569-570$.

${ }^{3} \mathrm{H}$. Wh e a to $\mathrm{n}$, Histoire des progrès du droit des gens, Leipzig 1853, s. 5 .

${ }^{4}$ K. Grzybows ki, Historia doktryn politycznych i prawnych, Warszawa 1968, s. 95 - 99, 101 - 102, 126 - 132; H. De m b iń s k i, Wojna jako narzędzie prawa i przewrotu, Lublin 1936, s. $16-17$.

${ }_{6}^{5}$ H. D. Rops, Kościót wczesnego średniowiecza, Warszawa 1969, s. 643.

6 Tom asz z A kwinu, Suma teologiczna, t. 16: Mitość (2a $2^{\text {ae }}$, quaestio $\left.23-46\right)$, Londyn 1967 , s. $235-244$. 
cza że stosunki między lennikiem a władzą zwierzchnią znajdowały się de facto jakże często w stanie ciągłego napięcia.

O wadze problemu świadczyć może to, iż ówczesne społeczeństwa poszukiwały jego rozwiązania niejako via facti już niespełna trzy wieki wcześniej, albowiem będąca przywilejem stanu rycerskiego tak zwana wróżda, czyli możność egzekwowania swych praw orężnie, srodze dała się ludziom we znaki. Wtedy to rodzi się instytucja pax Dei biorąca w obronę duchownych i biednych, a także ich dobra doczesne. Początek dały przysięgi feudałów - pospołu świeckich i duchownych — na synodach w Charroux (988 r.), Puy-en-Velay i Narbonne ( 990 r.) oraz Limorges (około 994 r.). Na przełomie X i XI wieku funkcjonowała ona, za sprawą Roberta Guillaume (duc d'Aquitaine), najpierw w hrabstwie Poitiers, a następnie na terenie całej Akwitanii. Idea ta, uniwersalistyczna w założeniu, zaczyna wkrótce promieniować na dalsze obszary dzisiejszej Francji, a następnie Europy zachodniej.

Próbą nadania jej bardziej konkretnego wyrazu i zarazem permanentnego charakteru była treuga Dei. Za jej inicjatora uchodzi papież Jan XV. Dopiero jednak na synodzie w Elne (1027 r.) ustalono, iż rozejm ów winien obowiązywać od soboty wieczorem do poniedziałku rano. Potwierdzono to na synodzie w 1040 r., ale dopiero synod w Caen (1043 r.) opatrzył go stosowanym do dzisiaj mianem. Ostateczną kodyfikację jego zasad przyniósł natomiast synod w Narbonne (1054 r.). W myśl uchwał, które tam powzięto, miał on obowiązywać w następujących okresach roku:

1. Od pierwszej niedzieli adwentu do oktawy trzech Króli 48 lub 42 dni

2. Od poniedziałku przed wielkim postem aż do $15 \mathrm{dni}$ przed Zielonymi Swiątkami

$105 \quad 105$

3. W suche dni, święta i ich wigilie

53 lub 39

4. W pozostałe niedziele roku

43 43

Łącznie:

249 lub 229 dni

Warto nadmienić, iż zasadniczo - mimo wspomnianej wyżej kodyfikacji w Narbonne - ustalenia te pochodzą de facto $\mathrm{z}$ okresu synodu w Tulujes w $1041 \mathrm{r}$. Tak więc, teoretycznie przynajmniej, dwie trzecie roku były okresem swoistego zawieszenia broni, a co cenniejsze — zasadzie owej poczęły zwolna hołdować także inne (poza Francją) kraje Europy. Tym większy był to sukces, jako że w pierwszej fazie treuga Dei ograniczała się jedynie do terytorium hrabstwa Roussillon.

Treuga Dei zawierała też w sobie zakaz stosowania sily przeciwko określonym stanom czy też pewnym kategoriom osób, takim jak rolnicy, duchowni, kupcy, studenci. Za przykładem Kościoła podążają monarchowie, ogłaszając pokoje cesarskie lub królewskie. Wyrazem tej myśli był gest cesarza Henryka III, który w roku 1043 ustanowił „dzień przebaczenia” a samą zasadę treuga Dei recypowano do Corpus iuris canonici. Równolegle jednak pojawiły się 
pierwsze oznaki nadużyć. Arcybiskup Bourges Aimon powołał w roku 1038 „miicję pokoju”, która później dopuściła się dość licznych wykroczeń i gwałtów ${ }^{7}$.

Niezmiernie pesymistyczną rekapitulację XI-wiecznych usiłowań w tej dziedzinie przekazał nam zakonnik Raul Glaber. Pisał on między innymi: „Wielekroć naruszano uroczyście zaprzysiężone umowy, tak jak napisane jest w Piśmie: utywszy i stłuściawszy odwierzgnął. Wielmoże obydwu stanów, popadając w chciwość, zaczynali od nowa swe rabunki tak, jak robili to przedtem

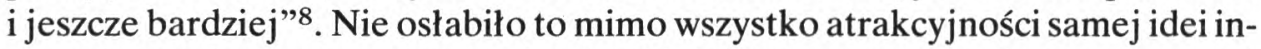
stytucji rozejmu, z tym że w wiekach późniejszych następowała stopniowa jej laicyzacja. Począwszy mniej więcej od połowy XII stulecia także cesarze starali się zawęzić stosowanie wróżby. Te po wielokroć powtarzane usiłowania nosiły nazwę ,pokoi ziemskich”. Podobnie jak poprzednio nakazywano wykluczenie z zakresu jej działania określonych osób, miejsc i rzeczy, a w wypadku złamania tych zakazów groziły kary analogiczne do kar za rabunek. Zmierzano też generalnie do stosowania jej jedynie w wypadkach, gdy zawiodła droga sądowa $^{9}$.

Podobne zabiegi podejmowali również królowie Francji. W XII wieku, w związku z rozwojem doktryny o suwerenności panującego, stał się on najpierwszym pokoju obrońcą i tu dopatrywano się źródła jego prawa do zapobiegania wszelkim formom bezrządu, w tym także wróżdom. Królowie Francji uciekali się w tej materii do dwóch posunięć: quarantaine-le-roi i asseurement. Pierwsza $z$ nich (czterdziestodniówka królewska) oznaczała zakaz atakowania krewnych skłóconych stron, którzy nie byli świadkami początków konfliktu, w okresie 40 dni od momentu podjęcia orężnej rozprawy. Drugie (assecuratio, zabezpieczenie) to zrzeczenie się stron, przed obliczem królewskiego urzędnika, prawa do stosowania sily. Początkowo był to akt dobrowolny, następnie urzędnik mógł to uczynić na wniosek jednej ze stron, wreszcie (w drugiej połowie XIII w.) został on uprawniony do czynienia tego z urzędu. Surowe kary nakłaniać miały poddanych do bezwzględnego przestrzegania tych kroków, niemniej król Ludwik IX nie osiągnął sukcesu, gdy w roku 1258 wprowadził zakaz toczenia wojen prywatnych ${ }^{10}$.

Zagrożone społeczności nie ustawały jednak w wysiłkach. I tak na przykład w roku 1386 francuskie Stany Generalne orzekły, iż poddanym króla (panował

7 J. Herge nröthe r, Historia powszechna Kościoła katolickiego, t. 5, Warszawa 1901, s. 122 - 125; A. Pr zy byls ki, Utopie, idee i projekty zwiqzku narodów i wieczystego pokoju, Warszawa 1932 , s. 11. H. D. Rops, jw., s. $644-645$.

${ }^{8}$ Cytuję za: J. B a s z kiewi wz, Myśl polityczna wieków średnich, Warszawa 1970, s. 128.

${ }^{9}$ K. Kon a r y i, Powszechna historia państwa i prawa, t. 3, Warszawa 1966, s. 20.

10 Przekonanie o tym, że władca winien stać na straży pokoju jest znacznie starsze, sięga IX wieku; J. B a s z ki e w i c z, jw., s. 126-127. Szczególnego znaczenia nabiera jednak dopiero w dobie rodzenia się teorii suwerenności; K. Grzybowski, jw., s. $169-170$; K. Kor a nyi, jw., s. 107. 
podówczas Karol VI Szalony) nie wolno dochodzić swych praw zbrojnie, nie tylko w czasie wojny, lecz i pokoju, a w niespełna wiek potem król Ludwik XI (1461 - 1483) raz jeszcze kategorycznie zakazał wojen pomiędzy szlachtą. Także w Rzeszy nie zasypiano gruszek w popiele. Za panowania cesarza Maksymiliana I ogłoszono na sejmie w Wormacji, w roku 1495, tak zwany „,wieczysty pokój krajowy". Odtąd wszelkie spory i przewinienia oceniane być miały przez właściwe sądy, co jak mniemano zapobiec miało skutecznie jakże licznym wojnom domowym ${ }^{11}$.

Równolegle niejako do zarysowanego wyżej procesu obserwować można tendencje do skanalizowania wojen w pożądanym przez niektórych dostojników Kościoła kierunku. Już papież Jan VII mniemał, iż chrześcijaństwo winno realizować się $\mathrm{w}$ walce $\mathrm{z}$ niewiernymi. Pełne rozwinięcie koncepcja ta znajdzie (i zarazem pociągnie za sobą doniosłe konsekwencje) w mowie wygłoszonej przez papieża Urbana II na synodzie w Clermont (1095 r.), gdzie zresztą zaprzysiężono także, po raz kolejny, treuga Dei. Kwestie te absorbowały w pewnej mierze również cztery pierwsze sobory laterańskie, a na ostatnim z nich (1215 r.) rozstrząsano problem pokoju między państwami chrześcijańskimi oraz odebranie Ziemi Swiętej z rąk niewiernych.

W wiekach późniejszych narodziła się praktyka arbitracji papieskiej, w indywidualnych sporach feudałów tak świeckich, jak i duchownych. Ich genezy należy się doszukiwać właśnie w zasadzie treuga Dei. Warto nadmienić, iż w XIII stulecia w samych Włoszech było aż 100 wypadków uciekania się do tego rodzaju rozstrzygnięć, gdzie mediatorem był albo sam papież, albo też (w razie jego nieobecności) specjalnie desygnowany arbiter. Cesarze znacznie rzadziej usiłowali stosować to rozwiązanie, albowiem książęta byli zbyt zazdrośni o swą świecką suwerenność. Logicznym krokiem wydawało się naonczas uczynienie z organizowanych ad hoc arbitracji papieskich instytucji stałej. W dziele napisanym w okresie III krucjaty (1190 r.) Geroh z Regensburga proponował, by papież zabronił wszelkich wojen, by książęta oddawali swe spory do załatwienia Rzymowi, by strona odrzucająca papieskie orzeczenie podlegała wyłączeniu ze społeczności chrześcijańskiej i pozbawieniu władzy. Zamysły te nie zyskały sobie jednak praktycznie żadnego posłuchu ${ }^{12}$.

Pośrednio nawiązywał do tych założeń Piotr Dubois (Petrus de Bosco) w swym dziele De recuperatione terrae sanctae, które ujrzało światło dzienne w 1306 roku. Jego podejście do zagadnienia wojny nosiło znamiona dychotomii. Z jednej strony potępiał bowiem zdecydowanie wszystkie wojny toczone między chrześcijanami, z drugiej — walkę z muzułmanami uważał za obowiązek. Wysnuł z tego wniosek, iż zadaniem podstawowym jest położenie kresu bratobójczym swarom. Możliwości realizacji tego celu upatrywał w kreowaniu

${ }^{11}$ H. D. Rops, jw., s. 645. W. Czapliński, A. Galos, W. Korta, Historia Niemiec, Wrocław 1981, s. 238.

${ }^{12}$ L. B eale s, Ład międzynarodowy wedtug nauki katolickiej, Londyn 1943, s. 29. 
organizacji stosującej zasady arbitrażu dla rozstrzygania zatargów. Stolica Apostolska miałaby natomiast być instancją ostateczną ${ }^{13}$.

Znacznie szersze cele postawil przed projektowanym przez siebie „Związkiem władców" zasiadający na tronie czeskim król Jerzy z Podjebradów (1458 - 1471). Do lansowania tego rodzaju koncepcji zainspirował go niebywały wzrost potęgi tureckiej. Konieczność obrony chrześcijańskiej Europy jawiła mu się z nieodpartą siłą. W tym celu winien powstać związek władców chrześcijańskich (Francji, Niemiec, Włoch i ewentualnie Hiszpanii). Stałyby przed nim zadania dwojakiego rodzaju: po pierwsze miałby on zapobiegać konfliktom zbrojnym pomiędzy członkami ugrupowania i strzec ich terytorialnej integralności, po drugie członkowie jego winni współdziałać w dziele oswobadzania ziem zajętych przez Turków. Co ciekawe, w ramach związku ani cesarz rzymski, ani papież nie otrzymaliby uprzywilejowanych pozycji. Cesarz brałby udział w obradach w charakterze króla Niemiec, dysponując jedynie równymi prawami z pozostałymi książętami niemieckimi, zawsze dopiero po władcy Francji, dla którego zastrzeżono prymat jako dla praesidens pater. Papież, z racji funkcji kapłańskich, nie mógłby teoretycznie być pełnoprawnym członkiem ugrupowania i praktycznie winien się ograniczyć do pośrednictwa między książętami nie będącymi uczestnikami związku. Jednakże projektodawca sugerował, by papież nakłaniał swym autorytetem opieszałych do składania stosownych danin, a nawet groził szczególnie opornym karami eklezjastycznymi. Była to kwestia o tyle ważna, że daniny owe stanowić miały podstawę dochodów związku i praktycznie decydować o możliwościach jego działania.

Naczelnym organem związku byłoby zgromadzenie (collegium, corpus universitatis, congregatio). Przewidywano nawet, że posiedzenie inauguracyjne odbędzie się w Bazylei, a następne - w pięcioletnich odstępach — zawsze w innym państwie członkowskim. Kolejnymi organami być miały: rada rządzących (consistorium) oraz międzynarodowy trybunał władców. Głosowano by podług grup narodowych, przy czym każda $\mathrm{z}$ nich dysponowałaby jednym głosem. Związek stanowiłby, generalnie rzecz biorąc, o pokoju i o wojnie, starając się wszakże zapobiegać w miarę możliwości tej ostatniej. Podstawą działania w tej materii miała być własna siła zbrojna i skarb. W projekcie statutu, składającym się z 23 artykułów, na szczególną uwagą zasługuje 13. z nich, zawiera bowiem zalążek tego, co współcześnie zwiemy „pokojowym współistnieniem"14. Niestety idea związku, godna ze wszech miar uwagi, nie została nigdy zrealizowana.

${ }^{13}$ Katolicyzm średniowieczny, red., J. Kelle r, Warszawa 1977, s. 61; R. L. Lo ne s, International Arbitration as a Substitute of War, Edinburgh 1907, s. 85-86; W. Cal y ń s ki, Piotr Dubois i jego plany wyzwolenia Ziemi Swiętej, „Przegląd Historyczny” 58: 1967. 2. s. $201-202$.

${ }_{14}$ J. Pog o n ow ski, Projekt zwiqzku władców Jerzego z Podjebrad, Warszawa 1932, s. 24 25; The Universal Peace Organisation of King George of Bohemia. A Fifteenth Century Plan for World Peace 1462 - 1464, ed. by F. K a v k a, Prague 1964, s. $22-29 ;$ R. He c k, Czeskiplan zwia$z k u$ wtadców europejskich z lat 1462 - 1464, [w:] Studia z dziejów polskich i czechostowackich, $\mathrm{t}$. 1., Wroclaw 1960 , s. $157-180$. 
Zwykle jednak znawcy przedmiotu doszukują się początków zasady pokojowego współistnienia w wieku następnym (projekt króla Jerzego pochodzi z lat 1462 - 1464). Po pierwsze, nawiązano podówczas trwalsze kontakty pokojowe - o prawno-międzynarodowym charakterze - ze światem muzułmańskim. W roku 1535 Franciszek I, ówczesny władca Francji, motywował w liście do papieża Pawła III konieczność zawarcia kolejnej kapitulacji ${ }^{15} \mathrm{z}$ Turcją następującymi względami: „Błędy ludzi i ich niedoskonałość nie pozwalają na zjednoczenie się w tej samej religii, ale różnica kultu, jak również zwyczajów, nie niszczy naturalnej społeczności ludzkiej". Po drugie, uczyniono pierwszy krok na drodze pogodzenia $z$ sobą różnych wyznań w ramach chrześcijaństwa. Znalazł on prawny wyraz w pokoju religijnym w Augsburgu (1555 r.), gdzie przyjęto zasadę: cuius regio eius religio. Jej sprecyzowanie i rozszerzenie nastąpiło natomiast $w$ traktaciẻ westfalskim (1648 r.). Klauzule tego dokumentu przewidywały bowiem równe prawa w cesarstwie dla książąt wszystkich wyznań: tak katolickiego, jak i protestanckich (przeciw czemu protestowało ze zrozumiałych względów papiestwo). Tak więc, teoretycznie przynajmniej, uznano za równe sobie wszystkie suwerenne państwa chrześcijańskie i nie wymagano odtąd wyznawania tej samej religii jako czynnika warunkującego wejścia do społeczności międzynarodowej ${ }^{16}$. Poszerzyło to niepomiernie zakres swobody poczynań w sferze polityki międzynarodowej.

Nic też dziwnego, iż wieki XVII i XVIII obfitują w projekty (momentami jakże nierealne) pacyfikacji świata. W r. 1623 Emeryk Crucé postulował w traktacie Le nouveau cynée utworzenie organizacji mającej stać na straży europejskiego status quo. Punktem wyjścia miałaby być petryfikacja zastanego porządku, jako że autor uznaje, iż istniejące granice, choćby z podbojów wynikłe, lecz czerpiące swe uprawnienia z dłuższego posiadania, winny być nietykalne. Umożliwiłoby to gwarantowanie członkom związku stałej niezawisłości i nienaruszalności ich terytorium. Crucé miał najpewniej zupełną pewność tego, iż zalegalizowanie możliwości terytorialnego rewizjonizmu przysporzyłoby Europie konfliktów o znacznym natężeniu i długotrwałości, a tym samym przekreśliłoby wszelkie ewentualne korzyści płynące $\mathrm{z}$ faktu istnienia jakiegoś pacyfistycznie zorientowanego ugrupowania międzypaństwowego. Zadziwiające, że w trzy wieki (z okładem) później wzorowali się na powyższym rozwiązaniu - nieświadomie zapewne - twórcy Organizacji Jednošci Afrykańskiej (1963 r.), uznając zgodnie za nienaruszalne - w imię nadrzędnego dobra powszechnego - granice pozostawione im przez kolonizatorów ${ }^{17}$.

${ }^{15}$ Kapitulacje to umowy zawierane od XV wieku między państwami chrześcijańskimi a Turcją, wprowadzające dla obywateli tych państw sądownictwo konsularne w Turcji. Zerwane zostały przez stronę turecką w 1914 r., a powyższy stan rzeczy usankcjonowal traktat lozański z 1923 r.; J. Ma k ow ski, Kapitulacje jurysdykcyjne, [w:] Encyklopedia podręczna prawa publicznego, red. Z. Cybich owski, t. 1, Warszawa (b. r. w.), s. $224-228$.

${ }^{16} \mathrm{R}$. B ierzan e k, Zasady prawne pokojowego wspótistnienia i ich kodyfikacja, Warszawa 1968 , s. $37-38$

${ }_{17}$ B. Winiars ki, Bezpieczeństwo, arbitraż, rozbrojenie, Poznań 1928, s. 12; Karta Organi- 
Następny z projektów lęgnie się na dworze króla Francji Henryka IV. Jeden z jego ministrów Maksymilian de Béthune, książę Sully, lansował ideę, której autorstwo, ze względu na jej dość — jak na ówczesne czasy — rewolucyjny charakter, przypisał swemu monarsze. W Lettre de $M$. de Sully au Roy (Henry le Grand) zaproponował autor utworzenie konfederacji 15 państw europejskich. Jej powstanie poprzedzono by pokojowym rozpatrzeniem stanu posiadania przyszłych sygnotariuszy. W skład tego związku miałyby wejść następujące kraje: 6 monarchii elekcyjnych (Stolica Apostolska, Cesarstwo, księstwo weneckie, Węgry, Polska i Czechy), 6 monarchii dziedzicznych: (Francja, Hiszpania, Anglia, Dania, Szwecja i Lombardia) oraz 3 republiki (Helwecja, Włochy i Belgia). Nad całością organizmu czuwałoby 6 rad prowincjonalnych i rada główna (conseil général), zlokalizowana w Europie środkowej, w skład której — na mocy trzyletniej nominacji — wchodziłoby 40 mężów z różnych państw, odznaczających się cnotą, prawością, rozumem i rozsądkiem. Unia nie nastawałaby w żadnej mierze na suwerenność swych członków, a spory załatwiałoby pokojowe pośrednictwo ${ }^{18}$.

Był to jednak pewien teoretyczny krok wstecz w porównaniu z rozwiązaniem proponowanym uprzednio. Po pierwsze bowiem zakładano korekty terytorialnego status quo, co niechybnie groziło otwarciem puszki Pandory w tym zakresie. Po drugie - pokój między członkami miał jedynie funkcje utylitarne wobec celu zasadniczego, sprowadzającego się do eliminacji posiadłości tureckich w Europie, podczas gdy Crucé rad był nadać swemu tworowi prawdziwie uniwersalistyczny charakter, gwarantowany m. in. udziałem właśnie Turcji, a także Persji, Chin, Tatarów, Wielkiego Księstwa Moskiewskiego, Maroka, Państwa Wielkiego Mongoła, Indii i innych państw afrykańskich. Różnice w skali i zamiarach ogromne do tego stopnia, że niektóre $\mathrm{z}$ nich próbowano wcielić w życie dopiero w XX wieku. Oba projekty odbiegały jednoznacznie od dotychczasowej praktyki, z tym że pierwszy z nich był zdecydowanie bardziej idealistyczny, a drugiemu w większym stopniu przyświecały realia stosunków międzynarodowych.

W tym kontekście godzi się natrącić o planie Anglika Wlliama Penna. W swym An Essay Towards the Present and Future Peace of Europe, pochodzącym z roku 1693, opowiadał się on za koniecznością powołania do życia swego rodzaju międzynarodowego parlamentu. Posłowaliby do tego ciała intelektualiści i przedstawiciele elity szlacheckiej wszystkich państw, a nadrzędnym celem obrad byłoby zapewnienie każdemu krajowi członkowskiemu bezpieczeń-

zacji Jedności Afrykańskiej. Zbiór dokumentów, Warszawa 1963; W. Petsch, Międzynarodowo - prawna ochrona terytorium państwa w systemie bezpieczeństwa zbiorowego, Warszawa 1978, s. 72 - 73. F. Ra motows k a, Przedmowa do: Zarys dziejów myśli pacyfistycznej, [w:] W. J. J ast r z ę bow s ki, Traktat o wiecznym przymierzu między narodami ucywilizowanymi. Konstytucja dla Europy, oprac. F. R o m a n ow s k a, Warszawa-Lódź 1985, s. $27-28$.

18 J. Pogonowski, jw., s. 30; A. Przybylski, jw., s. 20-23. 
stwa. W trzy lata potem François Fénelon proponował założenie trybunału powszechnego dla rozsądzania sporów między narodami i zapobieganiu tym sposobem rzeziom ${ }^{19}$.

Kolejną wersję pokoju wieczystego, idącą niekiedy bardzo daleko, zaprezentował Abbé de St. Pierre (Ch. I. Castel) w dziele: Projet de la paix perpétuelle pour l'Europe (1707 r.). Pomysł ów zasadzał się na idei powołania do życia związku państw, którego członkowie uznaliby za jeden z celów zasadniczych wspólną, znaczną redukcję wydatków wojskowych przy równoczesnym wzmożeniu bezpieczeństwa. Podstawą związku byłoby uznanie status quo i obrona granic państwowych, tak przed napaścią, jak i przed próbami rewizji pokojowej. W celu należytego zabezpieczenia suwerenności wszystkich członków zakazuje autor obdarzania jednej osoby dwoma koronami, zarówno w drodze dziedziczenia, jak i z wyboru. W sytuacji, gdy panujący zyskuje prawa zwierzchnie nad większym krajem, winien dotychczas dzierżoną władzę przekazać w inne ręce. Na czele związku stałby senat złożony z 24 posłów zrzeszonych monarchów. Quorum, niezbędne do podjęcia prawomocnej decyzji, stanowiłoby $3 / 4$ głosów. Siedzibę przewidziano w Utrechcie. Związek dysponowałby nadto międzynarodowymi sądami handlowymi, nałożony byłby nań obowiązek zwalczania przestępczości, spory załatwiałoby rozjemstwo. W tym wypadku znaczniejsi władcy dysponowaliby głosem wirylnym, mniejsi kurialnym. Pokojowa mediacja byłaby obligatoryjna, albowiem art. 8 projektu stanowił, iż „wielcy sprzymierzeńcy dla zakończenia swych zatargów, obecnych i przyszłych, wyrzekli się i wyrzekają na zawsze, za siebie i swych następców, drogi zbrojnej i zgadzają się na odwoływanie się odtąd do koncyliacji, do mediacji ze strony pozostałych sprzymierzeńców”. Kosztami funkcjonowania organizacji obarczano by jej członków proporcjonalnie do wysokości uzyskiwanych dochodów ${ }^{20}$.

W projekcie zwraca uwagę, oprócz wcześniej spotykanej zasady bezwzględnego poszanowania terytorialnego status quo, dążenie do przeciwdziałania rozwojowi imperializmu i hegemonii państw silniejszych oraz radykalne odcięcie się od wojny jako środka rozwiązywania problemów międzynarodowej społeczności. Na podkreślenie zasługuje też fakt, iż St. Pierre, w imię trwałości pokoju, zalecał zawarcie przymierza zaczepno-odpornego z państwami muzułmańskimi. Nie wahał się też zalecać ostrych sankcji przeciw temu członkowi, który nie tylko odmawia wykonania orzeczeń związkowych, lecz wręcz sposobi się do wojny. W takim wypadku gwałciciel statutu miałby być wspólnymi siłami z Europy usunięty, a państwo prowadzące działania wojenne przeciw kon-

19 P. Firstenberg, Gwarancje bezpieczeństwa wedtug paktu Ligi Narodów, Warszawa 1934, s. 18; F. de la Salign a c de la Mot te Fén el o n, Przypadki Telemaka syna Ulissesa, Warszawa 1775, s. 155; A. Przy by ls ki,jw., s. 26-27; B. Co mbe s de Patris, Fénelon précurceur de la Societe des Nations, „Revue d'Histoire Diplomatique” 39: 1925 s. 398 - 408.

${ }^{20} \mathrm{~J}$. W a r s z w s ki, Zagadnienie rozbrojenia w prawie międzynarodowym $i$ stosunkach międzynarodowych, Warszawa 1930, s. 48-49. F. R a m ot ow s k a, jw., s. $33-36$. 
federacji ponieść ich koszta. Były to więc zamysły dopracowane, starające się dopiąć nie tylko trwałego usunięcia zewnętrznych przejawów zła na arenie międzynarodowej, lecz i eliminacji ich przyczyn; zamysły wolne od wyznaniowej ksenofobii.

Podobne, choć rozumiane znacznie węziej założenia przyświecały również dwukrotnemu królowi Polski Stanisławowi Leszczyńskiemu (1677 - 1766; $1704-1709,1733-1735)$. Wychodził on z założenia, iż przyrodzonym stanem ludzkości jest pokój, a zyski płynące $\mathrm{z}$ wszelkich wojen bywały zawsze złudne. Poglądom swym dał wyraz w opracowaniu Mémorial de l'affermissement de la paix général, napisanym najprawdopodobniej wkrótce po pokoju w Akwizgranie w $1748 \mathrm{r}$.

Rozwiązaniem idealnym byłoby, zdaniem Leszczyńskiego, kreowanie „republiki chrześcijańskiej”, czyli „unii wszystkich państw chrześcijańskich”. Nie widząc jednak praktycznie żadnych szans na realizację tego typu zamierzeń, punktem centralnym swego planu czyni Francję Ludwika XIV. Aby objąć przywództwo owej unii, winna się ona pierwej wyrzec wszelkich dążeń do pozyskania dla siebie nabytków terytorialnych. Dalej, dzieli autor państwa europejskie na dwie zasadnicze grupy: monarchie i republiki. Do tych ostatnich zalicza w pierwszym rzędzie Anglię, Holandię, Szwecję, Polskę, Wenecję, kantony szwajcarskie i Genuę. Jego zdaniem w interesie tych „republik” nie leżą zdobycze, lecz zachowanie już posiadanych terytoriów, formy rządu i wolnoś$\mathrm{ci}^{21}$.

Jak widzimy podział został w zasadzie przeprowadzony pomiędzy monarchiami absolutystycznymi z tymi, w których spore odłamy społeczeństw wywierały aktywny, a często jakże wyraźny wpływ na charakter i kształt prowadzonej polityki. Warto też zanotować, iż Leszczyński nie widział możliwości urzeczywistnienia swych zamiarów bez pozyskania dla nich Francji, która jakkolwiek stanowiła podówczas modelowy przykład odrzucanego przezeń absolutyzmu, to jednak z racji potęgi stojącej do dyspozycji jej władców jawiła się jako nieodzowny element każdego poważniejszego ugrupowania europejskiego. W tej sytuacji autor proponował, by dla obrony pokoju wyżej wymienione republiki i Francja zawarły wieczyste przymierze (dla utrzymania zarówno posiadanych obszarów, jak i przywilejów wewnątrzpaństwowych) i wspomogły jego znaczenie zobowiązaniem się do niebrania udziału w swarach sąsiadów. Na czele nowego związku stanąłby król Francji. Do jego zadań podstawowych należałoby baczenie na rysujące się zagrożenia i oferowanie w związku z tym pokojowego pośrednictwa, a także w sytuacji krytycznej — udzielanie pomocy stronie uznanej za pokrzywdzoną i zarazem niezdolną do obrony ${ }^{22}$. General-

21 J. Ży cki, Memoriat Stanistawa Leszczyńskiego o zabezpieczeniu pokoju powszechnego, „Sprawy Obce” 2:1931 z. 8 s. $639-651$.

22 J. Ży cki, jw., s. $659-672$; L. E hr li ch, Prawo narodów i zagadnienia międzynarodowe w piśmiennictwie polskim od XV do XVIII w., „Rocznik Prawa Międzynarodowego” 1:1949 
nie powyższy koncept był kolejną próbą teoretycznego pogodzenia marzeń o wieczystym pokoju i bezpieczeństwie $\mathrm{z}$ realiami życia.

W niespełna dwadzieścia lat potem (1767 r.) narodził się dość obszerny projekt, będący w zasadzie mutacją znanych nam już rozwiązań. Jego autor von Lilienfeld domagał się dla chrześcijan stałego pokoju opartego o zafiksowanie ówczesnego status quo. Całością związanej z tym problematyki zawiadować miały kongresy, których forum competens byłby specjalny trybunał. Pierwsze z pokojowych zebrań obrałoby siedzibę owego ciała, wyznaczyło liczbę sędziów pokoju oraz personelu kancelaryjnego i uporało się z zagadnieniami regulaminowymi. Przyszłe zgromadzenia dawałyby wytyczne w sprawach prawno-politycznych, systematyzowałyby prawo państwowe. W skład związku wejść miało 20 krajów, wśród nich i Polska. Trybunał konstytułowałby prezes, 8 nadradców, radcowie i asesorzy: łącznie 69 osób. Siedzibą jego byłoby któreś $\mathrm{z}$ miast niemieckich, a językiem urzędowym francuski. Naczelne cele związku to: wpierw pacyfikacja, a potem rozbrojenie. Projekt statutu przewidywał też stosowanie sankcji przeciw tym członkom związku, którzy sprzeniewierzyliby się dobrowolnie przyjętym zobowiązaniom: zerwanie stosunków dyplomatycznych i przelanie władzy opornego na jego następcę 23 .

Warto w tym miejscu wspomnieć o prostych, ale jakąż naiwnością tchnących poglądach Jana Jakuba Rousseau, który domagał się „porządku pokojowego dla Europy jako całości", a w dziele zatytułowanym Uwagi nad rzadem Polski (1770 - 1771) wywodzil, iż „,wojska regularne jedynie do dwóch celów służą: aby napaść i podbić sąsiadów, aby obywateli okuwać w łańcuchy i obracać w niewolników". Panaceum na owe bolączki miało być zastąpienie wszelkich rodzajów sił zbrojnych milicją wyekwipowaną jedynie w lekką broń ${ }^{24}$.

Kolejny pomysł powszechnej pacyfikacji wyszedł spod pióra Kajetana Skrzetuskiego (wykładowcy Collegium Nobilium) w roku 1775. Jego zasadnicza treść zawierała się w pięciu punktach: (1) Skutkiem wieczystego między władcami lub stanami przymierza ich przedstawiciele zjeżdżać się będą na umówione miejsce, na którym wszelkie pretencje i zatargi rozsądzane być mają; (2). Każdy z panujących dysponować miał jednym głosem, a pierwsze zgromadzenie ustalić winno regulamin obrad i zadbać o zabezpieczenie finansowej strony całego przedsięwzięcia; (3). Zagwarantować miano prawa wewnętrzne poszczególnych członków, natomiast w sferze międzynarodowej punktem wyjścia miałyby być obowiązujące naonczas traktaty i umowy; (4) Opornych, nie akceptujących ustalonych zgodnie z procedurą postanowień, należało do tego kroku orężnie, aż do skutku, przymuszać; (5) Pełnomocnicy panują-

s. 144 - 145. Pewną rolę w zawarowaniu dla króla Francji (naonczas Ludwika XV) poczesnego miejsca w projektowanym związku odegrały też zapewne parantele Leszczyńskiego; zob. E. Rostwo rowski, Stanistaw Leszczyński - republikanin pacyfista, „Kwartalnik Historyczny” 77:1967 z. 2. s. $278-279$.

${ }^{23}$ J. Pogonowski, jw., s. 31; A. Przybylski, jw., s. 33-34.

${ }^{24}$ J. J. Rou s s e a u, Uwagi nad rzqdem Polski, Kraków 1924, s. $74-80$. 
cych mieliby prawo do ustanawiania większością 3/4 głosów potrzebnych rozporządzeń, ale nie mogliby przeprowadzać zmian w przedstawionych wyżej pięciu punktach „,kardynalnych"25.

Niejako ukoronowaniem XVIII-wiecznych usiłowań na polu zabezpieczenia pokoju jest niewielka praca Immanuela Kanta Zum ewigen Frieden, opublikowana w Królewcu w roku 1795 (zrodzona nota bene na marginesie jego właściwych zainteresowań), a formą przypominająca bardziej projekt aktu międzynarodowego niż dysertację filozoficzną. Całość składała się z dwóch zasadniczych części: wstępnej i definitywnej. Wstęp zasadzał się na sześciu punktach:

1. Żaden układ kończący wojnę nie może być uznany za traktat pokoju, jeżeli zawiera tajne klauzule wiodące do nowego starcia.

2. Żadne niezależne państwo nie może być nabyte przez inne państwo czy to w drodze dziedziczenia, czy też zamiany, kupna lub darowizny.

3. Z czasem mają przestać istnieć wszelkie armie stałe.

4. Nie wolno zaciągać pożyczek państwowych na wojny z innymi państwami.

5. Żadne z państw nie będzie miało prawa do narzucania siłą ustroju i rządu innemu państwu.

6. W razie wojny żadna ze stron nie może uciekać się do postępowania, które naraziłoby na szwank wzajemne zaufanie w czasie przyszłego pokoju (najniegodziwszymi przejawami takich poczynań było, zdaniem Kanta, nasyłanie morderców, trucicieli, łamanie postanowień kapitulacyjnych oraz zarządzanie zdobytym państwem przy pomocy renegatów).

Artykuły „definitywne” zakładały natomiast, że:

1. Ustrój obywatelski każdego państwa będzie republikański.

2. Federacja wolnych państw konstytuować będzie podstawę prawną stosunków między nimi.

3. Swiatowe prawa obywatelskie opierać się miały na zasadzie powszechnej godności.

Projekt zaopatrzony został także w tajny artykuł, w którym autor postulował, by przywódcy państw wpierw wysłuchiwali opinii filozofów, a dopiero potem uciekali się ewentualnie do użycia siły jako środka rozstrzygania sporów ${ }^{26}$. Sporo w powyższych propozycjach oświeceniowej wiary w dobroczynne skutki stosowania nauki i postępowych form życia społecznego.

Podobne poglądy, acz w formie i treści znacznie bardziej zubożone, glosił w tymże roku 1895 w Warszawie Ferdynand Nax, zalecając ,uformowanie z całego rodzaju ludzkiego jednej związkowej rzeczypostolitej". Nie taił przy tym, -492 .

${ }^{25}$ Księga pamiatkowa ku czci Oswalda Balcera, red. W. A br a ha m, t. 2, Lwów 1925, s. 490

${ }^{26}$ B. N a w roczy ń s ki, Kanta ,projekt wiecznego pokoju”, [w:] Filozofia pokoju, Warszawa 1971 , s. $150-156$. 
iż jego zdaniem najpoważniejszą przeszkodą na drodze tak wytkniętego celu będzie niechybnie niechętna postawa poszczególnych państw, gdyż akceptując szczerze to dążenie, musiałyby one wyrzec się części swej dotychczasowej niezależności ${ }^{27}$.

Również wiek XIX przyniósł w tej dziedzinie niemało nowych rozwiązań, chociaż zasadniczy nacisk położono jednak na zagadnienie zmniejszenia zbrojeń. Ciekawe koncepcje zapewnienia pokoju i stabilizacji, nawiązujące do planów z minionych stuleci, skonstruował ks. Adam Czartoryski (1770 - 1861). Zawarł je w trzech dokumentach. Dwa pierwsze z nich powstały w roku 1803. Autor mniemał, iż Rosja, kierując się szczerze pojmowaną zasadą „dobra powszechnego", mogłaby stać się arbitrem w Europie, uciekającym się do użycia siły jedynie w koniecznych wypadkach. Państwa mniejsze grupowałyby się w federacje zapewniające im warunek do bezpiecznego bytowania i rozwoju. Zdaniem Czartoryskiego najwłaściwsze byłyby następujące ugrupowania polityczne: francuskie, słowiańskie, niemieckie (ze Szwajcarią i Holandią, ale bez Prus i Austrii), włoskie. Grecy mogliby wejść w skład ugrupowania słowiańskiego, z tym że Słowian bałkańskich winno się przyłączyć do Węgier, wkomponowanych z kolei w Święte Cesarstwo Rzymskie Narodu Niemieckiego ${ }^{28}$.

Trzeci z dokumentów pochodzi z 1804 roku. Wstępnym warunkiem pokoju miała być victoria nad cesarzem Francuzów Napoleonem I (1804 - 1814), następnie zawarcie traktatu pokojowego, gwarantką którego byłaby Liga Europejska. Pierwsze skrzypce grałyby w niej Rosja i Anglia. Mniejsi sąsiedzi Francji jednoczyliby się w federacje, zdolne do stawiania oporu temu mocarstwu do czasu przyjścia im z pomocą przez potentatów Ligi, a znane już z poprzedniego planu ugrupowania niemieckie i włoskie stanowiłyby przeciwwagę dla Austrii i Prus. Liga ogłosiłaby „kodeks prawa narodów”, oparty na nowych zasadach współżycia międzynarodowego, pozwalający na pokojową egzystencję ludów Europy $^{29}$. Powyższe projekty nie rokowały jednak szans na urzeczywistnienie, tym bardziej iż Czartoryski pominął milczeniem palące kwestie przemian wewnątrzpaństwowych.

Kolejnym pomysłodawcą był sam car Aleksander I (1801 - 1825), który w liście do ówczesnego ministra spraw zagranicznych Anglii Henry'ego Roberta Stewarta, wicehrabiego Castlereagh $(1769$ - 1822), pisal w marcu 1816

27 Uwagi nad uwagami, czyli obserwacje nad ksiązka, która w roku 1785 wyszła pod tytutem „Uwagi nad życiem Jana Zamoyskiego" [F. Nax], Warszawa 1795, s. 120 - 122; S. Hu b e r t, Poglady na prawo narodów w Polsce czasów Oświecenia, Wrocław 1960, s. 187.

28 J. Sk ow ro n e k, Le programme européen du prince Adam Jerzy Czartoryski en $1803-$ 1805, „Acta Poloniae Historica”, 17: 1968 s. 141 - 147. Inne nieco koncepcje lansowal lord Mulgrave; zob. E. Ingram, Lord Mulgrave's Proposals for the Reconstruction of Europe in 1804, „The Historical Journal” 19:1976 nr 2 s. $511-520$.

${ }^{29} \mathrm{~F}$. R a m o tow sk a, jw., s. $65-66$. Z przełomu XVIII i XIX wieku pochodzi też projekt rosyjskiego dyplomaty W. Malinowskiego; J. Sk ow r o n e k, Notatka W. F. Malinowskiego o samostanowieniu narodów jako podstawie niezależnego politycznego bytu narodów, [Jassy - Petersburg 1801 — 1803] „Teki Archiwalne” 17:1978 s. 23 - 57. 
roku, iż równoczesna redukcja wszelkich sił zbrojnych mogłaby być najskuteczniejszym i uniwersalnym środkiem zagwarantowania nowego stanu rzeczy ${ }^{30}$ i przekonania wszystkich narodów w okresie pokoju o ich zupełnym bezpieczeństwie. Plan ten, autorstwa „władcy-mistyka”, wywołał co prawda pewną sympatię w kierowniczych kołach ówczesnej Europy, ale nie przyniósł żadnych praktycznych rezultatów. Zabrakło argumentów przemawiających za trwałością i szczerością intencji cara, okazało się bowiem dowodnie w rok potem (w trakcie anglo-rosyjskich nieporozumień na Bliskim Wschodzie) ${ }^{31}$, iż armia rosyjska nie została oczywiście poddana żadnym restrykcjom ${ }^{32}$.

Kolejnym przykładem głosownych deklaracji był los propozycji rozbrojeniowych króla Francuzów Ludwika Filipa I (1830 - 1848), wystosowanej pod adresem państw europejskich w roku 1831. W oparciu o nią przygotowano jedynie protokół, w którym Anglia, Francja, Austria, Rosja i Prusy uznawały „Z prawdziwym zadowoleniem, po dokładnym zbadaniu obecnej sytuacji w Europie, że szczęśliwie utrwalone stosunki zgody i dobrej harmonii między mocarstwami, oparte na niepodległości państw i na nienaruszalnej zasadzie utrzymania traktatu ${ }^{33}$, stwarzają dziś możliwość przyjęcia środka stanowiącego przedmiot najgorętszych życzeń ich rządów, a mianowicie powszechnego rozbrojenia" 34 . Pełna górnolotnych frazesów odezwa i tym razem pozwoliła zaledwie na ukojenie sumień.

Odmienny zupełnie charakter miał projekt Wojciecha B. Jastrzębowskiego (1799 - 1882), uczestnika powstania listopadowego, zatytułowany: Wolne chwile żotnierza polskiego, czyli myśli o wiecznym pokoju między narodami ucywilizowanymi, powstały na przełomie zimy i wiosny roku 1831. Składał się z dwóch części: historiozoficznej i projektu konstytucji dla Europy. Projekt ów tworzy 77 artykułów kreślących obraz przyszłości kontynentu. Założeniem generalnym jest twierdzenie, iż w obliczu Boga i prawa wszyscy ludzie, a zatem i narody są sobie równe. Prawa narodowe stanowić miałby sejm, a prawa europejskie kongres złożony z pełnomocników wszystkich narodów. Stróżem i wykonawcą praw narodowych były patryjarcha, a europejskich sam kongres. Drugim z kolei założeniem podstawowym była kasacja granic państwowych, jako że brak zgody co do ich przebiegu stanowił $\mathrm{z}$ reguły najczęstszą wojen przyczynę. Każdemu społeczeństwu należałoby jednak zagwarantować daleko idącą autonomię wewnętrzną. Kryterium przynależności do danego narodu stanowić miał fakt posługiwania się określonym językiem, bez względu na miejsce faktycznego zamieszkania. Narody rozproszone winny podlegać prawom nie tylko swego narodu, ale i tych pośród których zamieszkują.

Trzecim kardynalnym punktem były kwestie militarne. Wszelka broń cięż-

${ }^{30}$ Mowa o uchwałach kongresu wiedeńskiego.

${ }^{31}$ M. T a n t y, Bosfor $i$ Dardanele $w$ polityce mocarstw, Warszawa 1982, s. 95 - 99.

${ }^{32} \mathrm{P}$. Firstenberg, jw., s. $21-22$.

${ }^{33}$ Mowa o akcie Świętego Przymierza.

${ }^{34}$ J. Gilas, jw., s. $13-14$. 
ka stać by się miała własnością Europy. Część z niej zostałaby zlokalizowana w miejscach powszechnie znanych, wskazanych przez kongres, by mogła być w razie potrzeby wyzyskaną do obrony kontynentu. Drugą, zbyteczną partię, obrócono by na „wystawienie świątyni Bogu, opiekunowi praw i pokoju”. Narody z innych części świata miałyby prawo do przystąpienia do przymierza. Odstępstwa od akceptowanych powszechnie praw karanoby czasowym wykluczeniem ze związku. Gwoli utrwalenia pokoju zniesionoby na zawsze stałe wojska, natomiast utrzymanie wewnętrznego bezpieczeństwa wzięłaby na swe barki straż praw, w której obowiązywałby trzyletni okres służby. Wyposażona byłaby jedynie w broń myśliwską, opatrzoną godłem wiecznego pokoju ${ }^{35}$.

Przedstawione wyżej koncepcje cechowało dość wyraźne piętno utopii. W praktyce, w przeciągu minionych stuleci, znaczące rezultaty osiągnął Kościół katolicki, koncentrujący się w równiej mierze tak na teoretycznych dywagacjach, jak i na pacyfikacji konkretnych zajść orężnych. Wytworzyła się w związku z tym instytucja interwencji papieskich „na zaproszenie”. W latach 1598 - 1914 można by doliczyć się kilkudziesięciu ważnych tego rodzaju interwencji, przeprowadzanych osobiście przez papieży lub też ich specjalnych nuncjuszy $^{36}$. Próba mediacji podjęta została również przez Benedykta XV w sierpniu 1917 roku, kiedy to starał się równocześnie usilnie o zachowanie neutralności. W nocie skierowanej do przywódców państw walczących proponował przyjęcie następujących zasad, mogących stać się osnową przyszłego pokoju:

1. Prawo winno zatryumfować nad siłą.

2. Zmniejszenie podług stałych reguł i pod określonymi gwarancjami stanu zbrojeń do poziomu niezbędnego do zapewnienia w poszczególnych krajach spokoju publicznego.

3. Ustanowienie między narodami swobodnej komunikacji lądowej i morskiej.

4. Wzajemne wyrzeczenie się dochodzenia szkód i kosztów prowadzenia wojny.

5. Ewakuowanie zajętych w trakcie działań terytoriów należących prawnie do strony przeciwnej.

6. Wszelkie kwestie sporne, w tym także terytorialne, znaleźć się winny na wokandzie sądów rozjemczych, biorących pod uwagę wolę lokalnych społeczności ${ }^{37}$.

35 J. W. J a st rzę bows ki, jw., s. 164 - 197, 202 - 220 (konstytucja dla Europy), 221 - 225 (kilka myśli z projektu do konstytucji europejskiej z roku 1842). Podobne idee propagowal S. BuszCZYŃski (La décadance de l'Europe, Paris 1866). W sugerowanym przezeń związku narodów (coenopolia) niemałą rolę odgrywać mialy zasady etyki chrześcijańskiej.

36 J. Ep ps te in, A Catholic Tradition of the Law of Nations, Bura and Oates 1935, s. $470-$ 474; K. Rich te r, Wojna i pokój, Warszawa 1904, s. 95-99; G. B jö r klu nd, Pokóji rozbrojenie, Poznań 1895 , s. 86, 100-101. 133.

${ }^{37}$ Dokumenty wielkiej wojny europejskiej, wyd. W. Orłows ki, Warszawa 1918, s. 130 - 
Apel Watykanu nie pociągnął za sobą podówczas praktycznych następstw, ale szereg zawartych w nim myśli zostało w niedługim czasie wpisanych w teksty istotnych międzynarodowych deklaracji i traktatów.

Bardzo radykalny w treści okazal się uchwalony już 8 listopada (26 października) 1917 roku Dekret o pokoju. II Ogólnorosyjski Zjazd Rad, uznając wojnę za sprzeczną z interesami społeczności międzynarodowej, proponował w tym dokumencie narodom $\mathrm{i}$ ich rządom natychmiastową pacyfikację sytuacji bez aneksji i kontrybucji, przy czym przez aneksję rozumiano „przyłączenie do wielkiego lub silnego państwa małej lub słabej narodowości bez ściśle, wyraźnie i dobrowolnie wyrażonej zgody i chęci tej narodowości" 38 . Nie spotkał się on jednak z szerszym odzewem, jedynie Niemcy usiłowały go wyzyskać w sposób czysto koniunkturalny.

Więcej wagi przywiązywano do postanowień paryskiej konferencji pokojowej z roku 1919. W przyjętym wtedy pakcie Ligi Narodów (stanowiącym integralną część tak zwanych podparyskich traktatów pokoju ${ }^{39}$ ), nie postawiono co prawda wojny poza nawiasem prawa, ale art. 8 tegoż dokumentu stanowił, iż „członkowie związku uznają, że utrzymanie pokoju wymaga ograniczenia zbrojeń narodowych do minimum, dającego się pogodzić $\mathrm{z}$ bezpieczeństwem narodowym oraz z przymusowym przeprowadzeniem zobowiązań międzynarodowych przez wspólne działanie". Ten ostatni passus zapowiadał zbrojne poparcie dla członka organizacji - ofiary agresji, a tym samym odstraszać miał potencjalnych napastników. Dalej art. 12. wprowadzał obowiązek przedkładania sporów bądź specjalnemu sądowi rozjemczemu, bądź też radzie Ligi Narodów i wykluczał uciekanie się do użycia siły w trzymiesięcznym okresie po ogłoszeniu werdyktu. Postanowienia te precyzowały art. 13. i 15. a 16. przewidywał zastosowanie sankcji gospodarczych, finansowych oraz militarnych wobec agresora. Sam traktat wersalski z kolei obciążał Niemcy winą za wywołanie wojny, a art. 227. stanowil, iż „mocarstwa sprzymierzone i stowarzyszone stawiają w stan publicznego oskarżenie Wilhelma II Hohenzolerna, byłego cesarza niemieckiego, o najwyższą obrazę moralności i świętej powagi traktatów" ${ }^{40}$. Ostatnie z postanowień pozostało w sferze deklaracji, bowiem proces nigdy się nie odbył.

Liga Narodów nie ustawała początkowo w wysiłkach, by po pierwsze wyeliminować formalnie wojnę, a po drugie - stworzyć mechanizmy odstręczające od uciekania się do niej. Istotne znaczenie miało w tym zakresie IV zgromadzenie Ligi w 1923 roku, które przyjęło projekt traktatu o wzajemnej pomocy. Wstęp i art. 1. głosiły, że wojna napastnicza jest zbrodnią międzynarodową.

38 Prawo międzynarodowe..., s. $1-3$.

${ }^{39}$ Mowa o traktatach z państwami pokonanymi w I wojnie światowej.

40 Traktat pokoju między mocarstwami sprzymierzonymi i skojarzonymi i Niemcami, podpisany w Wersalu dnia 28 czerwca 1919 roku, „Dziennik Ustaw Rzeczypospolitej Polskiej” $1920 \mathrm{nr} 35$ poz. 200 s. $13-17,123$. 
Art. 2. zobowiązywał sygnatatriuszy do pomocy napadniętemu, ale tylko w sytuacji, gdy ten zredukował był swe siły zbrojne. Dalsze partie omawiają bardziej szczegółowo tak zagadnienia partykularnych umów obronnych, jak i procedury rozbrojeniowej ${ }^{41}$. Projekt ów nie zyskał jednak akceptacji rządów.

Kolejnym krokiem na tej drodze był protokół genewski, uchwalony przez V zgromadzenie Ligi w październiku 1924 roku. Podobnie jak poprzedni tekst wykluczał on wojnę napastniczą, obligował sygnatariuszy do redukcji zbrojeń, a użycie siły dopuszczal jednie w wypadku konieczności odparcia niesprowokowanej agresji. Zobowiązywał on także strony do uznania ipso facto za obowiązkową (w pewnych kwestiach) jurysdykcję Stałego Trybunału Sprawiedliwości Międzynarodowej. Niestety, mimo sygnowania go przez przedstawicieli 19 państw, podzielił on los swego poprzednika ${ }^{42}$. U podstaw odmowy legła negatywna decyzja Wielkiej Brytanii.

Niepowodzenie owo nie zraziło jednak państw mniejszych, były one bowiem szczególnie uwrażliwione na zagrożenie swej terytorialnej integralności. Warto w tym kontekście zwrócić uwagę na dwie deklaracje. Pierwsza to wniosek Polski - zgłoszony w trakcie VIII zgromadzenia Ligi Narodów — zawierający potępienie wszelkich wojen. Ostateczna jego wersja, przyjęta w formie nie zobowiązującej do niczego rezolucji we wrześniu 1927 roku ograniczała się jedynie (po raz kolejny) do potępienia agresji. Podobną w treści odezwę zaproponowała w lutym roku następnego VI konferencja panamerykańska obradująca w Hawanie ${ }^{43}$. Nie przywiązywano do nich jednak prawie żadnej wagi.

Od początku natomiast duże znaczenie moralne, a z czasem i faktyczne uzyskał zawarty w sierpniu 1928 roku pakt paryski, zwany też paktem BriandaKellogga. W art. 1. potępiono uciekanie się do wojny i uroczyście wyrzekano się jej jako środka rozstrzygania sporów międzynarodowych. Art. 2. zobowiązywał sygnatariuszy do stosowania wyłącznie metod pokojowych. Dokument ów uzyskał powszechną akceptację, albowiem do stycznia 1939 roku podpisało i ratyfikowało go 75 państw. Niemałe znaczenie miała też przyjęta w lipcu 1933 roku w Londynie konwencja definiująca pojęcia agresora i agresji. Projekt ten ujrzał światło dzienne w wyniku inicjatywy ludowego komisarza spraw zagranicznych Maksima Litwinowa i był przezeń lansowany w trakcie powszechnej konferencji rozbrojeniowej w Genewie. Pomysłodawca zakładał, iż za agresję uznać należy: wypowiedzenie wojny, najazd na terytorium innego kraju nawet bez wypowiedzenia jej, zaatakowanie przy pomocy sił zbrojnych obcego terenu, blokadę morską, poparcie użyczone uzbrojonym bandom ${ }^{44}$. Powyższe

${ }^{41} \mathrm{~J}$. W arszawski, jw., s. $163-164$.

42 Prawo międzynarodowe..., s. $243-252$ (dok. nr 64).

${ }^{43}$ A. Ta rnow s k i, Wniosek Polski na ósmem zgromadzeniu Ligi Narodów, „Przegląd Polityczny” 4 : 1927 t. 7 z. 1; A. G a u va i n, Projekty Paktu przeciwko wojnie, „Przegląd Polityczny” 5:1928 t. 8 z. 5-6.

${ }^{44}$ L. G e lbe rg, Pakt paryski z 27 sierpnia 1928 r., „Zeszyty Naukowe Szkoły Głównej Służby 
propozycje spotkały się z pozytywnym przyjęciem głównie w kręgu sąsiadów ZSRR.

Niepoślednie miejsce zajmuje takoż deklaracja moskiewska o powszechnym bezpieczeństwie z roku 1943. Chiny, USA, Wielka Brytania i ZSRR, będący naonczas czołowymi oponentami Niemiec i Japonii, oznajmiały w jej tekście że:

1. Istnieje konieczność utworzenia międzynarodowej organizacji, bazującej na równości wszystkich państw nastawionych pokojowo, stawiającej sobie za cel utrzymanie bezpieczeństwa i pokoju.

2. Akcji tej miały początkowo przewodzić, w porozumieniu z pozostałymi krajami, cztery mocarstwa.

3. Siły zbrojne mocarstw byłyby, po zakończeniu wojny, używane wyłącznie do realizacji celów niniejszej deklaracji.

4. Mocarstwa będą, wespół z innymi członkami Narodów Zjednoczonych, dążyły do wypracowania porozumienia w kwestii uregulowania zbrojeń ${ }^{45}$.

Tekst miał momentami dość ogólnikowy charakter, ale pozwoliło to na uniknięcie pokusy forsowania arbitralnych rozwiązań oraz na ofertę wciągnięcia do rzeczywistej współpracy wszystkich zainteresowanych.

Kolejnym ważnym i aktualnym po dzień dzisiejszy krokiem, będącym konsekwencją poprzedniego, okazało się podpisanie przez 46 państw w dniu 26 czerwca 1945 roku Karty Narodów Zjednoczonych. Przedstawiciele rządów, zgromadzeni na konferencji w San Francisco, potępili raz jeszcze zdecydowanie użycie siły, a zadanie utrzymania międzynarodowego ładu złożono na barki nowej organizaji. Odrzucono przy tym radykalne rozwiązania w rodzaju „komitetu czterech policjantów" 46 . Mimo wszelkich niedoskonałości stworzonego podówczas systemu, dzięki powszechności jego akceptacji i umiarkowaniu uczestników doniosła rola Narodów Zjednoczonych zdaje się nie ulegać wątpliwości.

Niemniej doniosłe znaczenie ma dla procesu eliminacji wojny realizacja drugiego z wymienionych na wstępie podpunktów: demilitaryzacji. Podane niżej przykłady posłużą jedynie do wyrywkowej ilustracji tego złożonego zagadnienia. Świat zna cały szereg precedensów rozbrojenia. Pierwsze z nich giną w pomroce dziejów. Podobno jeden z władców Chin, znany pod imieniem Pierwszego Cesarza Ch'in-Shih Huang Ti, rozkazał (III w. przed Chr.) prze-

Zagranicznej”, z. 1, Warszawa 1955, s. 94 - 103; Prawo międzynarodowe..., s. 350 - 353 (dok. nr 91). J. Ka ptos, Pakt Brianda-Kelloga, Kraków 1988.

$45^{\circ}$ T. Cy pria n, J. S a wi cki, Prawo norymberskie, Warszawa - Kraków 1948, s. 59-61; F. R y z k a, Na drodze do delegalizacji i kryminalizacji wojny, [w:] Norymberga - nadal otwarty rozdziat historii, Warszawa 1977, s. 220 - 222; W. T. Kow al ski, Wielka koalicja $1941-1945$, t. 1, Warszawa 1972, s. $558-559,710-711$ (ówczesne koncepcje w sprawie Narodów Zjednoczonych).

${ }_{46}$ Karta Narodów Zjednoczonych, wyd. L. E hrli c h, Kraków 1946, s. 36 - 38, 44 - 48. 
prowadzić rozbrojenie ludności, a uzyskany tą drogą metal stopić i przelać w dzwony oraz ogromne pomniki ${ }^{47}$.

W średniowieczu natomiast stanął na porządku dziennym problem zakazu stosowania w walce pewnych rodzajów broni. W wieku XII kuszę uważano za narzędzie godne jedynie niewiernych, które nie powinno być używane w starciach między chrześcijanami. Na soborze laterańskim II do jej publicznego potępienia doprowadził w roku 1139 papież Inocenty II. Zakazano pod klątwą stosowania „śmiercionośnej i Bogu nienawistnej sztuki kuszników i łuczników w stosunkach wzajemnych chrześcijan i katolików”. Przeszło pół wieku później papież Inocenty III poczuł się zmuszony przypomnieć o tej zasadzie, a sobór laterański IV wprowadził zakaz stosowania - w walce procarzy i łuczników. W rezultacie osiągnięto połowiczne efekty, jako że kusz przez dłuższy czas nie produkowano w Europie, a jedynie przemycano z krajów Bliskiego Wschodu. Przyczyniło się to początkowo do stosunkowo wąskiego zakresu jej użycia. W pierwszej połowie XIII wieku zalegalizował ten niecny proceder cesarz Fryderyk II Hohenstauf (1211 - 1250) nałożywszy na kupców powracających z Lewantu obowiązek dostarczania mu, w zależności od wyporności stat$\mathrm{ku}$, od 1 do 3 kusz, skutkiem czego w następnym stuleciu ten rodzaj broni był już szeroko stosowany ${ }^{48}$.

Pierwszą nowożytną umową rozbrojeniową był układ zawarty między Francją i Anglią w Wersalu w roku 1787. Oba państwa postanowiły nie powiększać swych zbrojeń morskich powyżej stopy pokojowej i nie zamawiać więcej niż po 6 okrętów, których budowę już rozpoczęto. Następny krok tego rodzaju uczyniono w kwietniu 1817 r., kiedy to doszło do zawarcia umowy pomiędzy Wielką Brytanią z jednej strony, a Stanami Zjednoczonymi z drugiej strony w sprawie ograniczenia zbrojeń na Wielkich Jeziorach. Na podstawie rzeczonego układu każda ze stron mogła posiadać w wyżej wymienionym rejonie po 4 okręty wojenne, których wyporność i uzbrojenie także bliżej określono. Warto dodać, iż zobowiązania do demontażu jednostek przekraczających ustalone limity wykonano w roku 1825 , a sama umowa zachowała (z pewnymi modyfikacjami) ważność po dzień dzisiejszy ${ }^{49}$.

Szereg traktatów zawarły także republiki południowoamerykańskie. Dużą aktywność na tym polu wykazały Peru i Kolumbia. Podpisały one dwa dokumenty: jeden w Limie w lipcu 1822 r., a drugi w Guayaquil we wrześniu 1829 r. Były to jednak porozumienia szczególnej natury, albowiem pełnić miały rolę podwójną: prócz ograniczonej redukcji zbrojeń, znajdujemy w ich tekstach klauzule czyniące $\mathrm{z}$ nich sojusze asekurujące sygnatariuszy w wypadku ewentu-

47 W. Rodzińs ki, Historia Chin, Wroclaw 1974, s. 76- 78.

${ }^{48}$ K. Kor a n y i, Problem broni zakazanej w XII w. , „Wojskowy Przegląd Prawniczy” 4:1948 $\mathrm{nr} 1$-2 s. 81 - 82; S. R y si a k, Rozbrojenie problem numer jeden, „Więź” $3: 1960 \mathrm{nr} 11-12$ s. 38.

49 J. Gilas, jw., s. 71 - 75; R. Bierzan e k, Wojna a prawo międzynarodowe, Warszawa 1982 , s. $29-31$. 
alnej interwencji Hiszpanii. Niemalejąca aktywność Peru doprowadziła do kolejnej ugody, tym razem z Boliwią, w sierpniu 1831 r. w miejscowości Tiquida, a następnie w tymże samym roku do porozumienia doszły Brazylia i Argentyna. Wreszcie w roku 1840 Peru i Boliwia ponownie podpisały układ rozbrojeniowy. Omawiając problemy Ameryki Łacińskiej, warto także natrącić o dwóch konwencjach pochodzących z początku naszego stulecia. W $1906 \mathrm{r}$. zmniejszenie swych zbrojeń deklarowały San Salvador i Honduras. Większe znaczenie przypisywano jednak umowie zawartej w 1923 r. przez Gwatemalę, Honduras, Kostarykę, Nikaraguę i San Salvador. Oba dokumenty dość radykalnie ograniczały siły zbrojne stron ${ }^{50}$.

Okres między dwiema wojnami światowymi obfitował tak w projekty rozbrojeniowe, jak i konkretne posunięcia w tej dziedzinie. Prawne i moralne zaplecze przygotowały dlań dwie konferencje haskie z lat 1899 i 1907 , humanizujące i kodyfikujące zasady prowadzenia wojen oraz zakazujące stosowania niektórych rodzajów broni ${ }^{51}$

Z kolei już u progu międzywojennego dwudziestolecia traktat wersalski przyniósł poważne uszczuplenie militarnych możliwości Niemiec $(100000$ Reichswehra) i stanowil, że Nadrenia będzie strefą zdemilitaryzowaną. Być może, iż wzorcem dla przyjętego podówczas rozwiązania była umowa z roku 1905 pomiędzy Szwecją i Norwegią, przewidująca utworzenie między tymi krajami pasa neutralnego z zakazem wznoszenia fortyfikacji w jego obrębie. Bezpośrednim rezultatem paryskiej konferencji pokojowej były też traktaty z państwami walczącymi w trakcie wojny u boku Niemiec. Etaty ich armii przedstawiały się następująco:

Austria (traktat z Saint-Germain-en-Laye)

30000 ludzi

Bułgaria (traktat $z$ Neuilly-sur-Seine)

20000 ludzi

Węgry (traktat z Trianon)

35000 ludzi

Turcja (traktat z Sévres)

50700 ludzi 52 .

Powyższy stan rzeczy sugerował też redukcję sił zbrojnych zwycięzców. Propozycję w tej materii przedłożył w lutym 1922 r. lord Esher. Jej istota polegała na powstaniu jednostki podstawowej, liczącej 30000 żołnierzy (współczynnik 1). Wybranym państwom europejskim przyznawał on prawo do następującego współczynnika: Francja - 6, Włochy i Polska - 4, Wielka Brytania, Holandia, Grecja, Hiszpania, Rumunia, Czechosłowacja i Jugosławia - 3, Portugalia - 1. Pomysł ów spotkał się z powszechną krytyką i nigdy nie rozwa-

${ }^{50}$ J. Gilas, jw., s. $36-38$.

51 Z. Cybichowski, Konferencje i kongresy, [w:] Encyklopedia..., s. 286 - 287, L. E hril ch, Prawo Narodów, Kraków 1947, s. 331 - 334, 404-406, S. N a hli k, Dorobek wielkiej kodyfikacji. W60 -lecie Konferencji Haskiej z 1907 r., „Państwo i Prawo” 22:1967 nr 12 s. 937-949.

52 Traktat pokoju... s. 95 - 96; Traktat pokoju między mocarstwami sprzymierzonymi i stowarzyszonymi $i$ Austriq, Warszawa 1919, s. 40 - 43; The Treaties of Peace 1919 - 1923, New York 1924, t. 1 s. 497 - 498 (traktat pokojowy z Węgrami), t. 2 s. 672 - 673 (traktat pokojowy z Bułgarią), t. 2 s. $834-836$ (traktat pokojowy z Turcją; traktat ten nie wszedl w życie: zob. G. R y siak, jw., s. 45). 
żano poważnie jego realizacji. Kwestię redukcji zbrojeń podniesiono także na moskiewskiej konferencji rozbrojeniowej (grudzień 1922 r.) oraz na V konferencji panamerykańskiej w Santiago (marzec 1923 r.). Obie zakończyły się także kompletnym niepowodzeniem ${ }^{53}$.

Kulminacyjnym punktem procesu ograniczania zbrojeń, aranżowanego pod auspicjami Ligi Narodów, była konferencja rozbrojeniowa w Genewie, obradująca od lutego 1932 r. i formalnie nigdy nie zamknięta, ale praktycznie prace jej zamarły już latem 1934 r. Zwołanie tej konferencji poprzedziły długie przygotowania: w latach 1921 - 1924 Tymczasowa Komisja Mieszana, a w okresie 1925 - 1930 Komisja Przygotowawcza do Konferencji Rozbrojeniowej. Zarówno w trakcie wstępnych negocjacji, jak i właściwych obrad, zgłoszono cały pakiet projektów zmniejszenia bądź też ograniczenia zbrojeń. Żaden $\mathrm{z}$ nich nie zyskał jednak powszećhniejszej akceptacji i nie wołał pozytywnych skutków ${ }^{54}$.

Odrębnym zagadnieniem były zbrojenia morskie. Udało się osiągnąć w tej dziedzinie pewne sukcesy. Pierwociny przypadają na połowę XIX stulecia, kiedy to w marcu 1856 r. podpisano układ neutralizujący Morze Czarne. Gwarantami tego postanowienia, opartego o traktat paryski ${ }^{55}$, stały się Wielka Brytania i Turcja. Następne akty notujemy już w wieku XX. Argentyna i Chile zawarły w maju 1902 r. konwencję zamrażającą ich aktualny stan posiadania na przeciąg lat 5, a następnie miała nastąpić redukcja tonażu flot. Rokowania kontynuowano i w styczniu 1903 r. podpisano w Buenos Aires protokół konkretyzujący rozmiary i zasady ograniczeń ${ }^{56}$.

W okresie międzywojennym kluczowe znaczenie miała konferencja waszyngtońska (listopad 1921 - luty 1922). Traktat waszyngtoński (będący jednym z jej rezultatów) zmniejszał stan posiadania czołowych potęg morskich o około 1800000 ton. Brytyjczycy zmuszeni zostali do rezygnacji z zasady „two powers standaed" i zaakceptowali następującą proporcję tonażu: w odniesieniu do USA - 5, Japonii - 3, 1, Francji - 1,75 i Włoch - 1,75. Powyższą pro-

${ }^{53}$ A. M. B rzezińs ki, Dyplomacja francuska wobec konferencji rozbrojeniowej w Genewie (2 II 1932 - 31 V 1937), Lódź 1987, s. 35 - 36; J. Ku m a n i e cki, Moskiewska konferencja rozbrojeniowa 1922 r., „Kwartalnik Historyczny” 77:1970 nr 2 s. 350-366; P. Est i e n n y, Le problème de la limitation et de la réduction des armements navals, Toulouse 1931, s., 86 - 87. Propozycję redukcji armii państw sąsiadujących, lub związanych z Niemcami przedłożono już w trakcie paryskiej konferencji pokojowej. Myślano nie tylko o krajach pokonanych. Oto dwie wersje ograniczeń odnośnie do wybranych państw:

Austria

Bułgaria

Czechosłowacja

Polska
I

15000 ludzi

10000 ludzi

22000 ludzi

44000 ludzi
II

40000 ludzi 20000 ludzi

80000 ludzi

Zob.: R. S. B a ke r, Woodrow Wilson and World Settlement, t. 1, New York 1922, s. 403 - 404.

54 W. Mich ow icz, Genewska konferencja Rozbrojeniowa (1932-1937) a dyplomacja pols$k a$, łódź 1984; A. M. B rzezińs k a, jw.

55 Mowa o traktacie kończącym wojnę krymską 1853 - 1856.

56 J. Gilas, jw., s. 39. 
porcję zastosowano jedynie wobec okrętów liniowych i lotniskowców. W sytuacji, gdy szereg podstawowych problemów nie zostało rozwiązanych, postanowiono kontynuować rokowania. Owocem tej decyzji były dwie nieudane konferencje: rzymska w lutym 1924 r. i genewska trwająca od czerwca do sierpnia 1927 r. Istotne uzupełnienia rezultatów Waszyngtonu przyniósł dopiero londyński traktat morski z kwietnia $1930 \mathrm{r}$. Ustalał on bowiem w pozostałych kategoriach okrętów (krążników i niszczycieli) proporcję w odniesieniu do Wielkiej Brytanii - 10, USA - 10 i Japonii - $7^{57}$.

Do kolejnego porozumienia w tej dziedzinie doszło następnie ( $\mathrm{z}$ udziałem Francji, ale bez Japonii i Włoch) w marcu 1936 r., jednakże w obliczu wyraźnego wzrostu napięcia międzynarodowego miało ono czysto techniczno-formalny charakter, podobnie zresztą jak bilateralne układy Wielkiej Brytanii z Niemcami, ZSRR, Polską i państwami skandynawskimi ${ }^{58}$. Wydarzenia te zamykają praktycznie międzywojenną fazę prac rozbrojeniowych, a wysiłki przypadające na okres powojenny stanowią ( $\mathrm{z}$ racji istnienia broni masowej zagłady) zupełnie odrębne zagadnienie.

Łacno dostrzec można fakty świadczące o tym, że dotychczasowe wysiłki zmierzające ku trwałemu pokojowi nie przyniosły ani trwałych, ani budzących optymizm rezultatów. Powojenna rzeczywistość, mimo wielości i różnorodności lansowanych od 1945 r. inicjatyw, także zapisała się w naszej pamięci licznymi rozczarowaniami. Warto jednak w związku z powyższym przypomnieć stosowne uchwały Soboru Watykańskiego Drugiego, obradującego od października 1962 r. do grudnia 1965 r. Wykraczają one co prawda poza ramy chronologiczne niniejszej pracy i nie pretendują do miana konkretnego planu pokojowego, ale $\mathrm{z}$ drugiej strony dostrzegają $\mathrm{w}$ dzisiejszych czasach sporo pozytywnych wartości i kreślą zarazem rzeczowy program działań na przyszłość.

W konstytucji Gaudium et spes postuluje sobór w kwestii wojny i pokoju zajęcie następującego stanowiska:

1. Podkreśla konieczność dochowywania umów lagodzących okropności wojen: „79. Istnieją w sprawach wojny różne umowy międzynarodowe podpisane przez wiele narodów w tym celu, aby bardziej ludzkimi uczynić działania wojenne oraz ich następstwa [...]. Umów tych należy dochowywać, [...] władze publiczne i rzeczoznawcy w tych sprawach zobowiązani są dokładać wszelkich starań, jakie tylko leżą w ich mocy, aby umowy te były przestrzegane, przyczy-

${ }^{57}$ S. Roskili, Naval Policy between the Wars, t. 1: 1919-1929, London 1968, s. 300 - 355, $433-515$; toż, t. 2: $1930-1939$, London 1976, s. $37-70,544-560$; A. M. B rzeziń s k i, Stanowisko Francji wobec waszyngtońskiej konferencji rozbrojeniowej, [w:] Acta Uniwersitatis Lodziensis. Folia Historica 28, Łódź 1986, s. 13 - 33; J. Ła p to s, W. Roj e k, Francja wobec problemu zbrojeń na konferencji waszyngtońskiej, „Dzieje Najnowsze” 18:1986, nr 1., s. 3 - 15.

${ }^{5}$ S. R os kill, jw., t. 2 s. 284 - 321; W. Ro je k, Druga londyńska konferencja morska 1935 -1936, [w:] Acta Universitatis Lodziensis..., s. 127 - 140. 
niając się w ten sposób lepiej i skuteczniej do pohamowania okropności wojen"59.

2. W istniejącej sytuacji „wojny ze spraw ludzkich nie wypleniono. Póki zaś będzie istniało niebezpieczeństwo wojny [...], póty rządom nie można zaprzeczać prawa do koniecznej obrony, byle wyczerpywały wpierw wszystkie środki pokojowych rokowań"60.

3. Wypowiada się przeciw wszechogarniającej wojnie: „80. [...] obecny Swięty Sobór solidaryzuje się z potępieniem wojny totalnej przez ostatnich papieży"61.

4. Postuluje nieodzowność podejmowania w dalszym ciągu wytrwałych zabiegów o utworzenie władzy publiczenej, stojącej na straży pokoju: „82. [...] usilnie trzeba nam się starać, aby wszystkimi siłami przygotowywać czas, kiedy za zgodą narodów będzie można zakazać wszelkiej wojny. Wymaga to oczywiście ustanowienia jakiejś powszechnej, przez wszystkich uznawanej władzy publicznej, która by rozporządzała skuteczną siłą, zdolną wszystkim zapewnić zarówno bezpieczeństwo, jak i przestrzeganie sprawiedliwości oraz poszanowanie praw" 62 .

5. Zakłada niezbędność zmiany wychowania, wprowadzenie „odnowy wychowywania umysłów oraz nowej orientacji w opinii publicznej"63.

6. Domaga się usuwania pośrednich powodów sporów: „Chcąc zaprowadzić trwały pokój należy przede wszystkim wyplenić przyczyny konfliktów, które przeradzają się w wojny, zwłaszcza zaś przejawy niesprawiedliwości: zbytnie nierówności gospodarcze, żądza panowania, pogarda dla człowieka, ludzka zazdrość, nieufność" 64 . W tym kontekście zaznacza też konieczność lepszej i ściślejszej wspólpracy odpowiednich organizacji międzynarodowych i podkreśla ogromną ich rolę.

Uchwały soboru akceptują istniejący stan rzeczy jako punkt wyjścia. W drodze do celu, którym ma być świat bez wojen i przemocy, należałoby tymczasem doskonalić istniejące już mechanizmy strzegące pokoju, przekształcać świadomość społeczeństw, nie zaniedbując zarazem dążeń do stworzenia instytucji dbającej o pokój w skali globalnej. Fundamentami jej miałyby być: z jednej strony powszechne uznanie narodów, $z$ drugiej jednak strony system skutecznych sankcji, eliminujących trwale gwałt i przemoc. Zakładany proces przemian, osadzony mocno w realiach, prowadzić by miał do głębokich przemian

${ }^{59}$ Konstytucja duszpasterska o Kościele w świecie wspótczesnym Gaudium et spes, [w:] Sobór Watykański Drugi, Paris 1967, s. 639.

${ }_{60}$ Tamże, s. 639. J. I m b a ch (Wielkie tematy soboru, Warszawa 1985, s. 14 - 15) pisze w komentarzu, iż sobór w profetycznych słowach potępił wojnę i ludobójstwo, ale nie zaprzeczył zupeInie i w pewnych warunkach prawa do obrony.

61 Gaudium et spes... s. 641.

62 Tamże, s. 643.

63 Tamże, s. 645.

${ }^{64}$ Tamże, s. 645 - 647; A. B i l iń s k i, Wtadza polityczna w doktrynie II soboru watykańskiego, Poznań 1981, s. 106-107. 
tak w sferze stosunków międzynarodowych, jak i sposobu myślenia i bycia jednostek. Konstytucja rekapituluje dotychczasowe, skromne dokonania, stwarzając równocześnie wizję odmiennego świata, bazującego na zasadach moralnych, wspólnych dla chrześcijaństwa i odmiennych światopoglądów.

Powyższe wywody świadczą dobitnie, że problem eliminacji wojen i rozbrojenia zaprzątał od zarania umysły ludzi. Los tych zamysłów łatwy był jednak do przewidzenia: spotykały się one częstokroć $\mathrm{z}$ formalnym uznaniem, ale faktycznie darzono je drwiną, lub - w najlepszym razie - źle skrywaną niechęcią. Rysem charakterystycznym przytłaczającej większości projektów są wskazania ich autorów na bezwzględną konieczność akceptacji status quo (najczęściej terytorialnego). Zalecenie owo, przywodzące poniekąd na pamięć postępowanie Aleksandra Macedońskiego w Gordion, stanowiło w istocie jedyną szansę zdecydowanego przekreślenia wiekowych swarów i trwałego ukształtowania polityki międzynarodowej na odmiennych zasadach. Wypada wszakże nadmienić, iż realność owego kroku była i jest nadal wielce dyskusyjna.

Drugą cechą godną wyeksponowania jest niewątpliwie znamienna ewolucja od zabiegania o pokój w ramach jednej społeczności wyznaniowej, poprzez akceptacją faktu istnienia innych wspólnot chrześcijańskich i innowierczych, aż do tendencji uniwersalistycznych, zakładających jednak poszanowanie - w inię rzeczonego pokoju - wszelkich niesprzecznych z nim odrębności, zachowanie których wydaje się istotne z punktu widzenia danego społeczeństwu.

W sferze konkretnych pomysłów rozbrojeniowych wykazano się nie mniejszą inwencją, ale $\mathrm{z}$ reguly nie kreślono przed sobą tak ambitnych celów. Zainteresowanie koncentrowano najczęściej bądź to na eliminacji określonych broni, bądź też na zawężeniu możliwości wywoływania konfliktów zbrojonych (sfery neutralne). Szeroko lansowano również różnorakie ilościowe i jakościowe ograniczenia, które miałyby być nałożone na przygotowania wojenne.

W procesie zapewnienia trwałego pokoju i powściągnięcia zbrojeń niepoślednia rola przypada w udziale Kościołowi katolickiemu, tak w kwestiach materialnych, jak i ideologicznych. Szczególną odpowiedzialnością w tej mierze obarczyło go średniowiecze $\mathrm{z}$ racji jego miejsca w życiu politycznym, społecznym i gospodarczym. Okazał się on podwóczas inicjatorem wielu praktycznych posunięć, zwłaszcza w zakresie zawężenia stosowania oręża. Czasy nowożytne przyniosły co prawda wyraźną laicyzację idei pokoju i rozbrojenia, ale nadal wielu możnych tego świata i myślicieli mniemało, iż papiestwo winno być zwornikiem i gwarantem nowych układów służących zachowaniu pokoju. Niemałą 
aktywność przejawiała też dyplomacja watykańska, a także lokalni przedstawiciele Kościoła, zwłaszcza w oferowaniu mediacji zwaśnionym stronom. Wreszcie współcześnie położył Kościół niebagatelne zasługi w dziele kształtowania postaw moralnych sprzyjających pokojowi. Fakt, iż wysiłki zarówno Kościoła, jak i instytucji świeckich, mimo znacznych momentami sukcesów, nie dały do tej pory trwalszych rezultatów, nie zwalnia bynajmniej od podejmowania dalszych zabiegów w tym kierunku.

\section{ZUR PROBLEMATIK DES DAUERHAFTEN FRIEDENS IN DER GESCHICHTLICHEN FASSUNG}

\section{Zusammenfassung}

Den Inhalt vorliegender Erwägungen stellen zwei Probleme dar: die Illegalität der Krige oder seiner bestimmten Erscheinungen und die Demilitarisierung, Angesichts der Mannigfalt der Initiativen auf diesem Gebiet wurde die Darstellung auf die stichweise Exemplifikation wichtigeren Punkte dieser Prozesse, bei der gleichzeitigen Beseitigung ideologisch-doktrinären Hintergrundes, beschränkt. Zur Veranschaulichung des Charakters der Illegalität wurden sowohl die Projekte, die in der Sphäre der Theorie geblieben sind, als auch die, die in konkrete diplomatische Akte verwandelt wurden, zugezogen. Die Domäne der Demilitarisierung bilden demgegenüber Pläne der Abrüstung, mittelbar also der Verminderung der Kriegsgefahr.

Ursprünge der friedlichen Koexistenz kann man schon im Altertum suchen, ein tiefgreifender Umbruch auf diesem Gebiet ist aber erst nach dem Geburt des Christentums vollbracht. Die Kirche stimmte mit den Gedanken der radikalen Pazifisten, die den Krieg als der Glaubensprinzipien widersprüchlich betrachteten, nicht überein. Dem Staate wichtige Funktionen in der Organisation und Schutz des weltlichen Lebens beimessend sah sie in der Waffe ein wirksames Mittel zur Beibehaltung der mit dem Staat verbundenen Werte. Obengenannte Fragen wurden zum Erwägungsthema vieler Philosophen und Staatsmänner.

Das Schicksal der meisten Antikriegskonzepten war jedoch eindeutig: formell wurden sie anerkannt, tatsächlich aber mit Ironie, Abneigung oder Gleichgültigkeit angenommen. In der Regel wurden sie in Anlehnung an die notwendige Anerkennung des Status quo aufgestellt. Das stelIte de facto die beste Chance zur Wiederlegung der andauernden Feindseligkeiten und dauerhaften Gestalltung der internationalen Beziehungen nach den neuen Regeln. Den anderen wichtigen Zug stellte die Evolution von dem Streben nach dem Frieden innerhalb einer Konfessionsgesellschaft durch die Anerkennung anderer christlichen und andersgläubebigen Gemeinden bis zu den universellen Tendenzen, die auf der Anerkennung — im Namen des angestrebten Friedens - aller widerspruchslosen Eigentümlichkeiten, deren Beibehaltung aus dem Standpunkt der gegebenen Gesellschaft wichtig war, fusste. Auf dem Gebiet der Abrüstungskonzepten zeigte man nicht mindere Erfindungsgabe, die Zielsetzung aber war nicht so weitreichend. Man beschränkte sich meistens entweder auf die Beseitigung bestimmter Waffenarten oder auf die Beschränkung der möglichen Konfliktfeldern.

Im Streben nach dem dauerhaften Frieden spielte die katholische Kirche wesentliche Rolle. Besondere Verantwortlichkeit wurde ihr im Mittelalter auf Grund ihrer Stellung im politischen, gesellschaftlichen und wirtschaftlichen Leben zugeschrieben. Sie wurde damals zum Anreger vie- 
ler praktischer Schritte zur Beseitigung der Waffe aus dem täglichen Leben. Die Neuzeit brachte mit sich Verweltlichung der Idee des Friedens und der Abrüstung, viele Philosophen und Staatsmänner waren jedoch der Meinung, daß eben das Papsttum zum Garanten und zum Schlußstein neuer friedenstiftender Gruppierungen sein sollte. Wesentliche Aktivität im Aussöhnen stritenden Seiten wies die päpstliche Diplomatie und die ortlichen Vertreter der Kirche nach.

Die Tatsache, daß die Bestrebungen sowohl der Kirche als auch der weltlichen Institutionen bis heute, trotz einiger momentan wichtiger Erfolge, keine anhaltenden Resultate gebracht haben, entbindet nicht von der Pflicht, weitere Handlungen auf diesem Gebiet aufzunehmen. 